\title{
Self Diagnosis of Web-Based Pregnancy and Childbirth Disorders Using Forward Chaining Methods
}

\author{
I Putu Agus Eka Pratama \\ ${ }^{1,3}$ Department of Information Technology, Faculty of Engineering, Udayana University, Jimbaran, Bali, Indonesia
}

\begin{tabular}{|c|c|}
\hline Article Info & ABSTRACT \\
\hline & \multirow{10}{*}{$\begin{array}{l}\text { The high mortality rate for pregnant women and childbirth in Bali, Indonesia, } \\
\text { is caused by a lack of initial diagnosis of the diseases and complaints } \\
\text { experienced by pregnant women during pregnancy, as well as a lack of health } \\
\text { medical personnel scattered throughout Bali, to be able to provide optimal } \\
\text { health services. It is necessary to have an online information system that } \\
\text { helps pregnant women to be able to independently and online diagnose } \\
\text { diseases, complaints, and symptoms experienced during pregnancy. The } \\
\text { system must be able to be accessed anytime and anywhere, with high } \\
\text { reliability and availability, and provide fast diagnostic results. The focus of } \\
\text { this research is the design and implementation of an Information System for } \\
\text { Diagnosis of Pregnancy Disorders Based on Cloud Computing using } \\
\text { Forward Chaining Method, with the Design Science Research Methodology } \\
\text { (DSRM) and the Technology Acceptance Model (TAM) method. The } \\
\text { application is placed on the Hybrid Cloud to make it more secure and } \\
\text { reliable. The results of this research, help the pregnant women to do online } \\
\text { self-diagnosis, to reduce the mortality rate for pregnant women and giving } \\
\text { birth. }\end{array}$} \\
\hline Received Nov 11, 2020 & \\
\hline Revised Dec 20, 2020 & \\
\hline Accepted Jan 11, 2021 & \\
\hline Keywords: & \\
\hline Diagnosis & \\
\hline DSRM & \\
\hline Forward Chaining & \\
\hline Pregnancy Disorders & \\
\hline TAM & \\
\hline
\end{tabular}

This is an open access article under the CC BY-SA license.

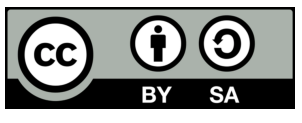

Corresponding Author:

I Putu Agus Eka Pratama,

Department of Information Technology, Faculty of Engineering,

Udayana University,

Jl. Raya Kampus Unud, Bukit Jimbaran, Badung, Bali, Indonesia.

Email: eka.pratama@unud.ac.ids

\section{INTRODUCTION}

The data from the Bali Provincial Health Office (Indonesia: Dinas Kesehatan Provinsi Bali) shows that the mortality rate for pregnant women and giving birth in Bali Province is quite high [1]. This is due to a lack of early diagnosis and treatment related to complaints experienced by pregnant women, as well as a lack of health medical personnel in all areas of Bali Province, to be able to provide optimal health services to pregnant women. With the availability of information technology, it will be possible for pregnant women and health medical personnel to be able to find out and diagnose the initial complaints experienced by pregnant women during pregnancy and before delivery, so that early prevention and treatment can be carried out. It is necessary to develop an online information system that can help pregnant women to independently diagnose diseases, complaints, and symptoms experienced during pregnancy and before pregnancy.

The system must be able to be accessed anytime, anywhere, and from any device via an internet connection. The system should also have high reliability and availability. For this reason, in this study, a web-based information system is proposed using the Forward Chaining method. The system was developed using the Design Science Research Methodology (DSRM), which was then 
tested on the developer side using the Black Box Testing method and user testing using the Technology Acceptance Model (TAM) method. The system is built based on Cloud Computing.

Research using Forward Chaining methods at several fields, purposes, and case study, has been conducted by some of previous researches. Zahrih and Findawati using Forward Chaining method to develop an expert system of ovarian cyst disease diagnosis based on web [2]. Ajlan on his research, describes the comparison of both Forward Chaining and Backward Chaining is a method at the expert system application development [3]. Muludi et al., in their publication, explain the use of the Forward Chaining and Certainty Factor Method in the form of an Android based expert system for tomato diseases identification [4]. Prambudi, et al., develop an expert system application for the decision of contraception tools choice, using Forward Chaining and Certainty Factors Method [5]. Poningsih introducing their research about the web-based expert system application using forward chaining method, to diagnosis of disease teak [6].

Pramesti describes her research that develop an expert system based on forward chaining method to determine the type of lenses glasses [7]. Rupnawar describes her research about the study of comparison both Forward Chaining and Backward Chaining in case of Artificial Intelligence [8]. Sasmito, et al., present their research about the development of expert system application using Forward Chaining Method and the rule-based reasoning for simulation diagnose pest and disease red onion and chili plant [9]. Hayadi, et al., develop an expert system application as a tool for learning model at the University of Pasir Pengaraian, using Forward Chaining Method [10]. Adriyendi on his paper, focus on the concept of knowledge representation in Artificial Intelligence and implementing of Forward Chaining method on food affordability, that used to planning of food in the future [11].

Gunawan and Wardoyo in their research describe the solution for insomnia patients treatment using expert system applications based on the certainty factor method, to accommodate uncertainty about symptoms and rules that used a measure of increased belief (MB) and a measure of increased disbelief (MD) [12]. Setiabudi, et al., make an expert system based on android platform on their research, to help the dentist to detect dental disease, with $95 \%$ accuracy rate [13]. Saputri, et al., using Certainty Factor Method in the form of a web-based application to handling the uncertain condition in hepatitis diagnosis with BlackBox Testing [14]. Setyaputri et al., on their research have compared and analysis both of Certainty Factor Method and Bayes Probability Method in case of Ear, Nose, and Throat (ENT) diseases, where Certainty Factor Method has accuracy in diagnosing the disease by $100 \%$ and the Bayes Probability method of system accuracy is $80 \%$ [15].

Purnama, et al., describe their research about the use of the Certainty Factor Method in case of detecting children's intelligence, using expert system application [16]. Latumakulita in her research explained about the development of an expert system application to diagnose childhood diseases using the Certainty Factor Method [17]. Yulianti, et al., in their research, create an expert system with the certainty factor method, to help psychologists and educators or instructors seeing the modalities or learning styles of adolescents, so that they can determine learning styles [18]. Achmadi, et al., in their research develop a desktop-based expert system application to diagnose of virus infection disease in children with Certainty Factor Method, using MySQL [19]. Minarni and Fadhillah, described their research about rice plant diseases and how to detect it using Certainty Factor in the form of web-based expert system [20].

Dan and dudeck introducing their research about the implementation of the certainty factor method in a Hospital Information System based on an expert system [21]. Cruza and Beliakovb in their research, present a method of determining certainty factors from statistical data using nonlinear regression and illustrate it with a leukemia diagnostics problem [22]. Sumartono, et al., present their research about an expert system of catfish disease using Certainty Factor Method, that very helpful for farmers to improve catfish farming [23]. Yuhandri on his research, focus on building an Expert System application for the diagnosis of Osteoporosis disease using certainty factor, based on the web (PHP MySQL) [24].

Panggabean on his research describe the development of artificial intelligence technology on expert systems to be applied in detecting stroke using both of Dempster Shafer method and the 
Certainty Factor method and compare it [25]. Annisa develop an expert system application to detect the mental disorders of type schizophrenia using Certainty Factor and tracking techniques with Forward Chaining method and knowledge data that can be updated according to the development of knowledge [26].

Siti, et al., develop the expert system based on the web using the Forward Chaining method for diagnosing rubber plant diseases is the best solution to recognize the symptoms of the disease in rubber plants as early as possible, find out the cause of the disease and how to control it [27]. Yusra develop an expert system based on forward chaining and certainty factor diagnosis was undertaken with the aim to help the process the result the diagnoses damage to a smartphone, so that they do not take a long time to make sure the result the diagnoses further, with the result of 73,33\% [28]. Robby develop an application based on Forward Chaining to diagnose Covid19 that uses a continuous trace system that will detect every symptom experienced by the patient, in the case of Pandeglang Banten, Indonesia [29]. Pahlevi and Atmojo develop an Android-based application to diagnose the disease of cocoa plant using Forward Chaining, where tracking begins with the selection of symptoms experienced than the results of the diagnosis in the form of cocoa plant diseases reported [30]. Putri, et al, develop a web-based application using the Forward Chaining method to knowing someone's personality by some of the questions to the user [31]. Syhaputri, et al., design and implementation the expert system based on the web to analyzed oily facial skin using the forward chaining method, which was caused by various kinds of symptoms that attack everyone's facial skin, especially oily facial skin disease [32].

Research on the information system for diagnosing pregnancy disorders to pregnant women, also has been conducted by some of previous researches. Abdillah, et al., proposed an expert system based on web using Forward Chaining method, to give the obstetric and antenatal care for pregnant women, to diagnose the 13 types of the illness or diseases [33]. Aji, et al., describe their research about the use of Certainty Factor (CF) in the form of digital expert system diagnosis of diseases of pregnant women [34]. Maryani and Haryanto designed an expert system using the Forward Chaining method, to find out diseases suffered by pregnant women, where disease data are based on existing facts, through interviews and references [35]. Hasbiyanor and Bahar, develop an expert system based on web using Certainty Factor method, to help midwife in diagnosing diseases pregnant women rapidly [36]. Afiana, et al., focus on develop an expert system desktop based application using Forward Chaining method, to help midwives and obstetricians in diagnosing disorders that occur during pregnancy caused by symptoms that appear, with the case study at Purwosari East Java (Indonesia) [37].

Meanwhile, some of previous researcher of expert system for diagnosing pregnancy disorders, using another method than Forward Chaining and Certainty Factor. Mustafa and Kusrini in their research, describe about the development of a web-based expert system for diagnosing pregnancy disorders using Bayes Theorem, with the case study of Jayapura, Papua Province (Indonesia) [38]. Minardi and Suyatno developed an expert system using Dempster-Shafer Theory to diagnose pregnancy disorders with mathematical representations [39].

All of these previous researches have contributed to develop an application using Forward Chaining and Certainty Factor or another method (Bayes Theorem, Dempster-Shafer Theory), but it is not effective, not reliable in the network, and did not including woman pregnant as main user to testing the application. In this research, the main contribution is the use of Cloud computing technology on the application, the use of the Technology Acceptance Model (TAM) for user testing, and including the user (pregnant woman) to diagnosing herself using this application. It can make the application more effective and reliable to users in case of a pregnant woman to diagnose herself.

\section{RESEARCH METHOD}

This study aims to optimize the results of the diagnosis of disorders in pregnant and childbirth women using the Forward Chaining Methods. Design Science Research Methodology (DSRM) was used in this study, with 8 sequential steps as shown in Figure 1 below: 

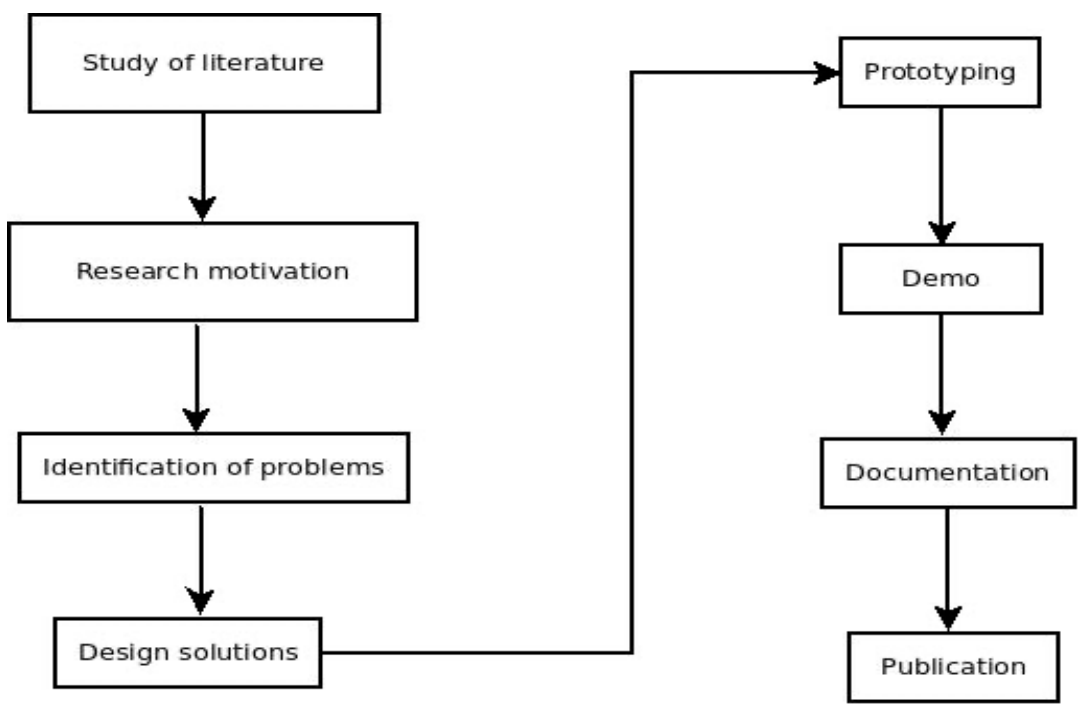

Figure 1. Design Science Research Methodology (DSRM) with 8 steps

\subsection{Literature Study}

Data obtained from literature studies and case studies in the field, to determine the weight of the criteria for each symptom of disease and disorders in pregnant and childbirth women. The weight of each symptom is carried out through the use of a questionnaire to the user, to support the Forward Chaining method with some data in a table.

\subsection{Data Collection}

Pregnancy disorders in pregnant women and giving birth, have various types, where each type has many symptoms. Table 1 presents the types of diseases and disorders that can be identified in the system:

Table 1. Type of disease and disorders at pregnancy and childbirth woman

\begin{tabular}{|c|c|c|}
\hline No & Disease & Disorder \\
\hline 1 & Chronic Hypertension & $\begin{array}{l}\text { Blood pressure greater than } 120 / 80 \mathrm{mmHg} \text {, gestational age less than } 20 \\
\text { weeks, proteinuria, have a history of hypertension before pregnancy, } \\
\text { multiparous, there is a history of decreased hypertension in the family }\end{array}$ \\
\hline 2 & Superimposed Pre-Eclampsia & $\begin{array}{l}\text { Blood pressure greater than } 120 / 80 \mathrm{mmHg} \text {, gestational age less than } 20 \\
\text { weeks, proteinuria, have a history of hypertension before pregnancy }\end{array}$ \\
\hline 3 & Gestational Hypertension & $\begin{array}{l}\text { Blood pressure greater than } 120 / 80 \mathrm{mmHg} \text {, gestational age more than } 20 \\
\text { weeks, proteinuria, proteinuria is persistent, experiencing heartburn, have } \\
\text { thrombocytopenia }\end{array}$ \\
\hline 4 & Mild Pre-Eclampsia & $\begin{array}{l}\text { Blood pressure greater than } 120 / 80 \mathrm{mmHg} \text {, gestational age more than } 20 \\
\text { weeks, proteinuria, proteinuria yield more than } 300 \mathrm{mg} / \text { day }\end{array}$ \\
\hline 5 & Severe Pre-Eclampsia & $\begin{array}{l}\text { Blood pressure greater than } 120 / 80 \mathrm{mmHg} \text {, gestational age more than } 20 \\
\text { weeks, proteinuria, platelets less than } 100,000 \mathrm{~mm} 3 \text {, Proteinuria yield } 2.0 \\
\text { g/day, having oliguria, urine volume/day less than } 400 \mathrm{ml} / \text { hour, blood } \\
\text { pressure increased }>160 / 110 \mathrm{mmHg} \text {, stunted fetal growth, have increased } \\
\text { levels of the enzyme ALT or AST, LDH/Lactate Dehydrogenase is increased, } \\
\text { have a severe headache }\end{array}$ \\
\hline 6 & Eclampsia & $\begin{array}{l}\text { Blood pressure greater than } 120 / 80 \mathrm{mmHg} \text {, gestational age more than } 20 \\
\text { weeks, proteinuria, having a seizure that occurs is comprehensive }\end{array}$ \\
\hline 7 & Epilepsy & $\begin{array}{l}\text { Normal blood pressure or equal to } 120 / 80 \mathrm{mmHg} \text {, have a seizure, have a } \\
\text { history of epilepsy }\end{array}$ \\
\hline 8 & Malaria & $\begin{array}{l}\text { Normal blood pressure or equal to } 120 / 80 \mathrm{mmHg} \text {, headache, fever, stiff neck, } \\
\text { disorientation, loss of consciousness }\end{array}$ \\
\hline 9 & Migraine & $\begin{array}{l}\text { Normal blood pressure or equal to } 120 / 80 \mathrm{mmHg} \text {, headache, visual } \\
\text { disturbances, vomiting }\end{array}$ \\
\hline 10 & Tetanus & $\begin{array}{l}\text { Normal blood pressure or equal to } 120 / 80 \mathrm{mmHg} \text {, trismus, muscle spasm, stiff } \\
\text { in the face, stiff in the neck, stiff in the nape, stiff stomach }\end{array}$ \\
\hline 11 & Hypotension & $\begin{array}{l}\text { Blood pressure less than } 120 / 80 \mathrm{mmHg} \text {, frequent fatigue, fainting, depression, } \\
\text { stress, difficulty concentrating }\end{array}$ \\
\hline
\end{tabular}




\subsection{Requirement Analysis}

At this Requirement Analysis stage, the analysis is taken from the collected information about disease and disorders of pregnancy and childbirth women, to support the process of developing the program. After getting the required information, subsequently, all prerequisites were analyzed and defined to complete the system. This phase found functional and non-functional requirements before developing the application based on the web.

\subsection{System Design}

The design was developed after reaching a complete definition of the prerequisites from the Requirement Analysis phase. The development of a system using an object-oriented paradigm, so that UML must be created. A Flow Chart Diagram and Use Case Diagram was created, as shown at Figure 2 and Figure 3 below.

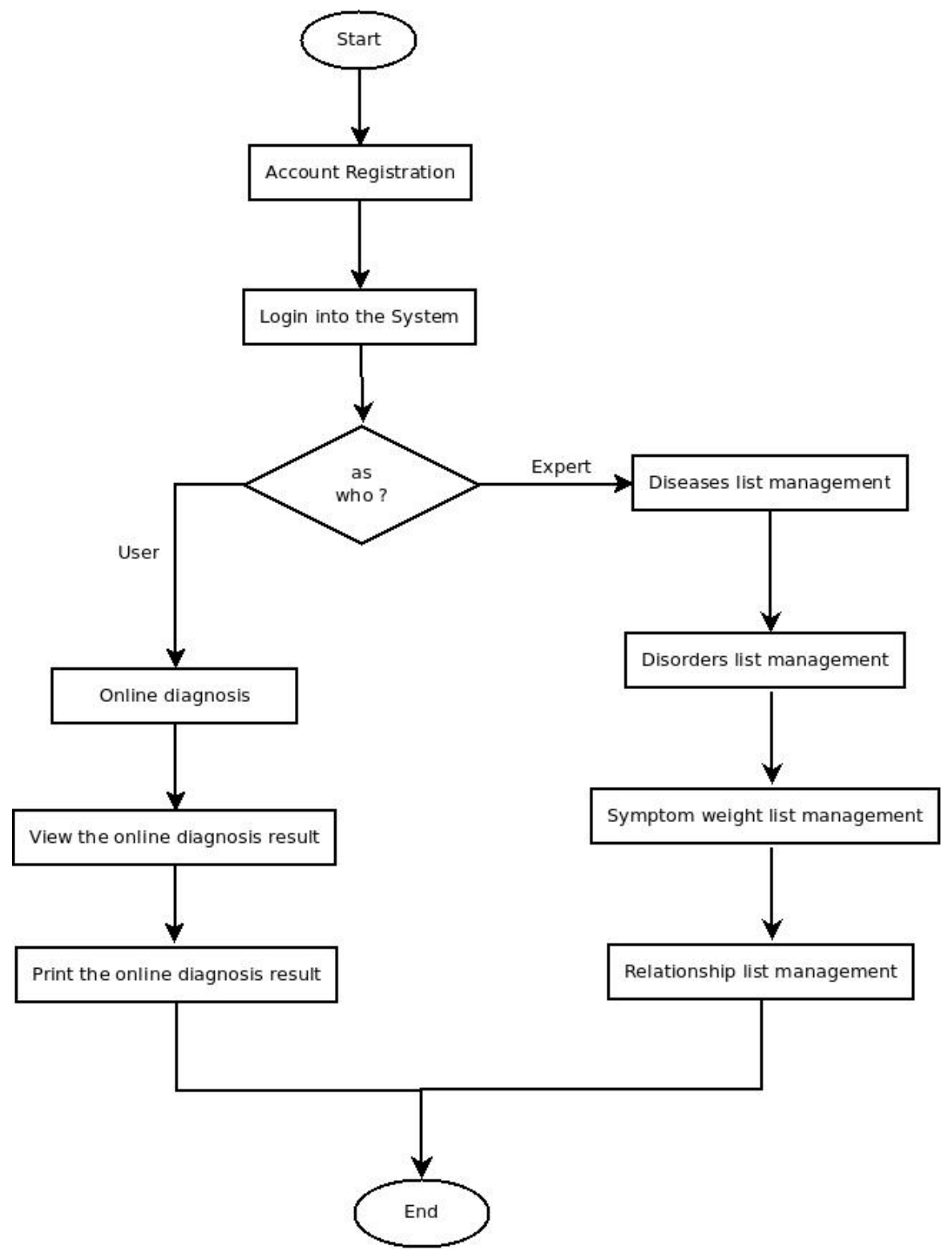

Figure 2. Flow Chart Diagram 


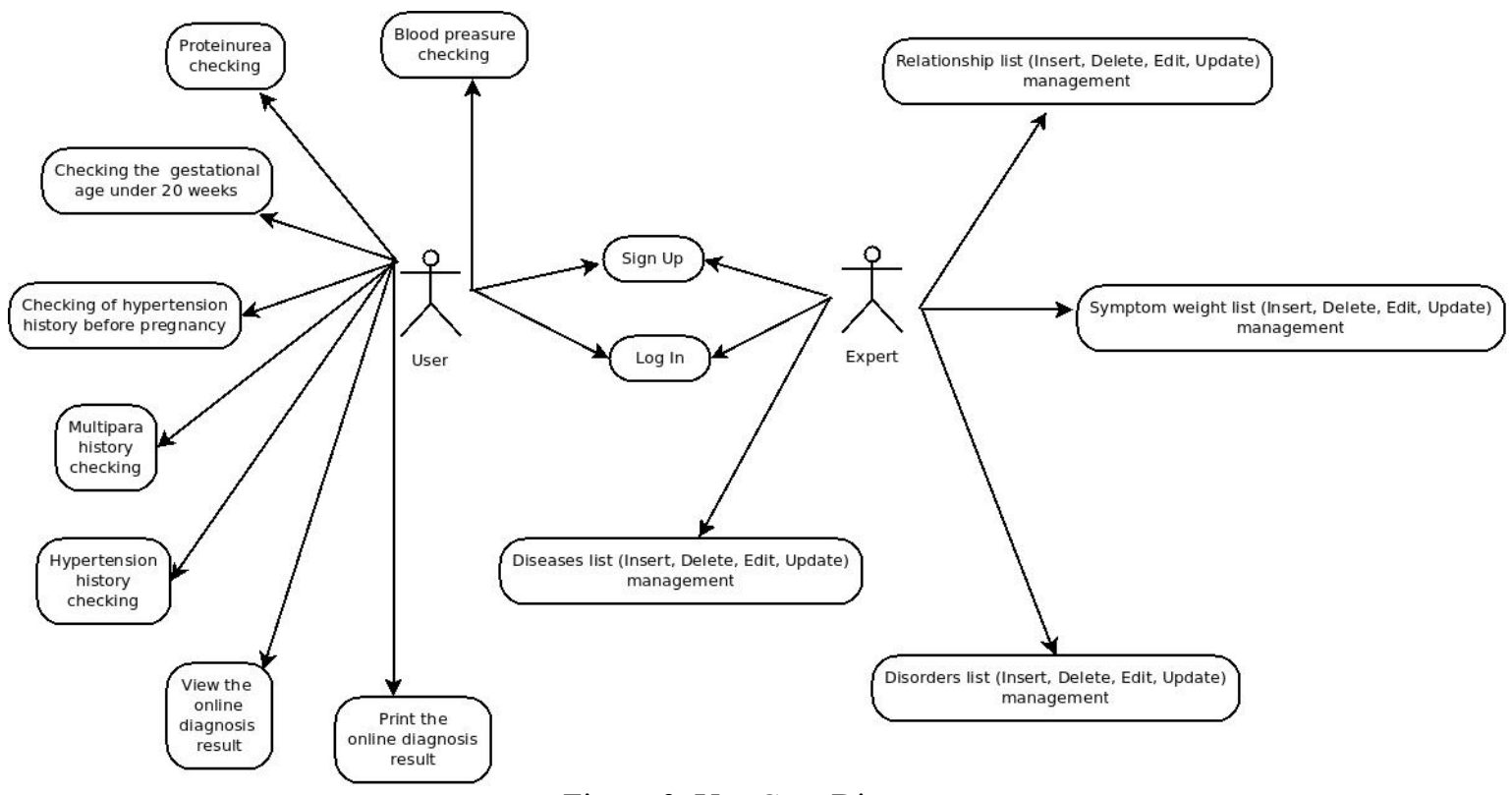

Figure 3. Use Case Diagram

\subsection{Forward Chaining Implementation}

Forward Chaining method is one of the method that based on inference engines with condition-action rule. In the Forward Chaining method, the data used to determine which rules will be executed consecutively. The process will be repeated until an outcome has been located.

Based on Fauzan and Prananda rules on their research [40], the use of the Forward Chaining on expert system will be presented as three rules below:

Rule 1: If the premise 1 And the premise 2 And the premise 3 Then the conclusion 1.

Rule 2: If the premise 1 And the premise 3 And the premise 4 Then the conclusion 2.

Rule 3: If the premise 2 And the premise 3 And the premise 5 Then the conclusion 3.

Rule 4: If the premise 1 And the premise 4 And the premise 5 And the premise 6 Then the conclusion 4.

Based on these rules, in the implementation of the web application, the user login into the system, answers the questions based on the premises (diseases and disorders) from the list displayed by the application. Based on the selected premises, the application will search for the appropriate rules. Afterward, the conclusions can be retrieved and show to the user in the form of an online diagnosis result.

\subsection{Hybrid Cloud Design and Implementation}

As the network and resource infrastructure, this research using both Public Cloud and Private Cloud in form of Hybrid Cloud. The Cloud Computing system implementation using both of Openstack and Kubernetes on Ubuntu Linux operating system, including with Virtual Machine (VM) and stack. With the Hybrid Cloud form, users can access it from both public network (internet) and private networks, with the power of Cloud Computing technology in resource computation on Cloud Virtual Machine and Kubernetes stack, to make it more secure and reliable on network. The design and implementation of Hybrid Cloud Computing, shown in Figure 4 and Figure 5 as below: 


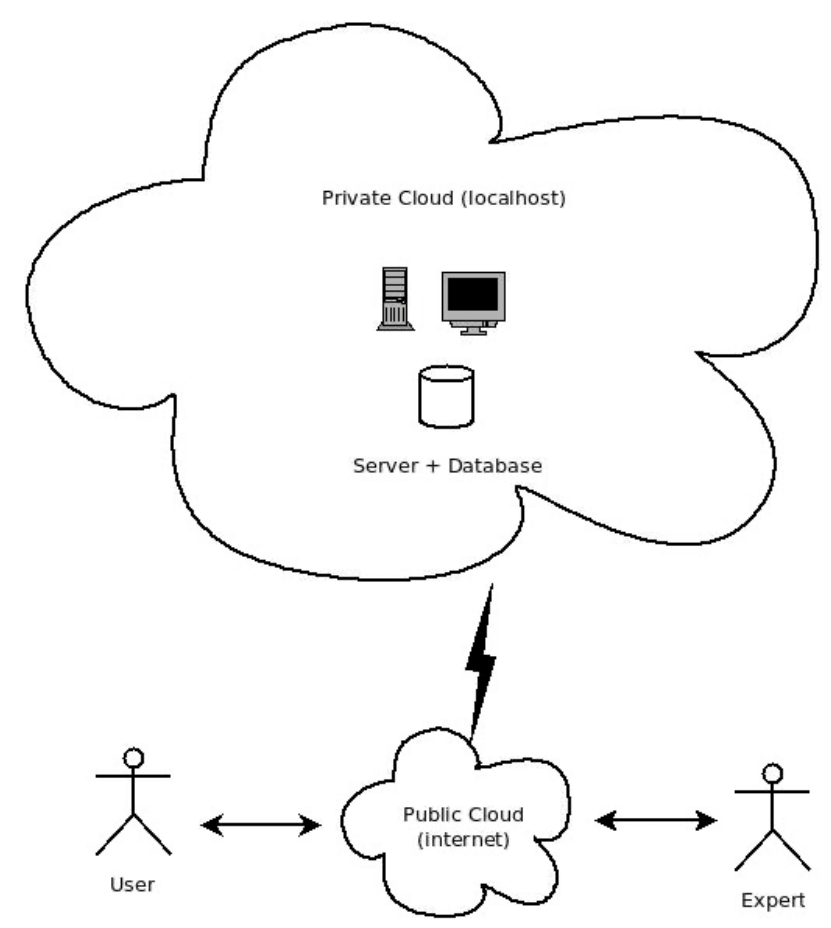

Figure 4. Hybrid Cloud Design

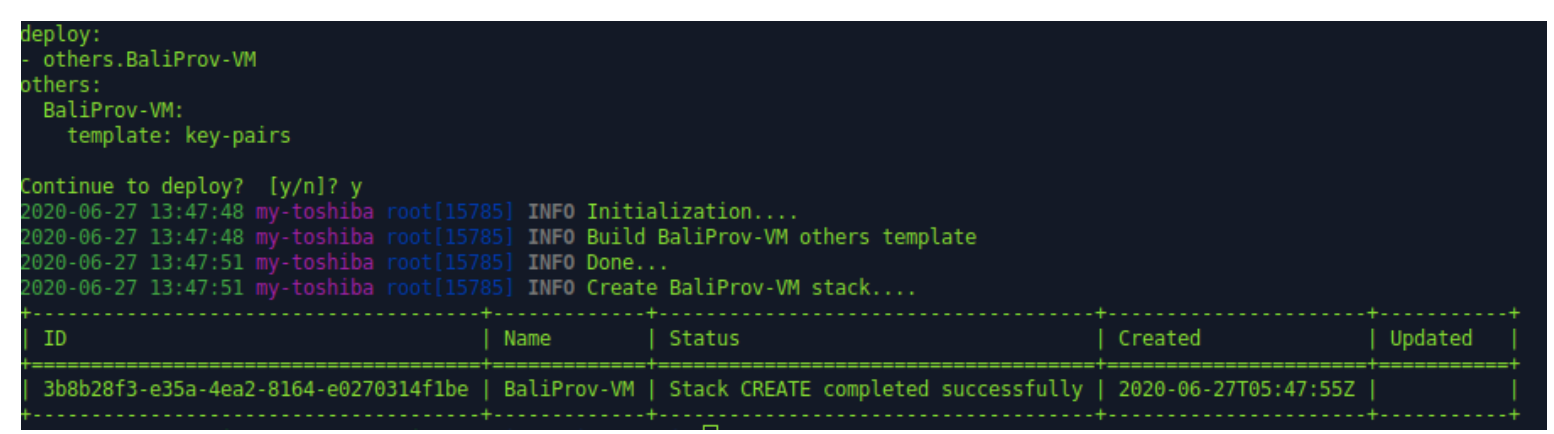

Figure 5. Hybrid Cloud Implementation

\section{RESULTS AND DISCUSSION}

\subsection{Diagnosis Phase of Diseases and Disorders Using Forward Chaining}

The system starts from the data initialization for disease symptoms of pregnancy and childbirth woman and then displayed on the system. In this case, pregnancy and childbirth woman login to the system as a user, then answers some of the questions regarding their symptoms. Then if there are additional symptoms, they will be reinserted until all symptoms are completely inputted. Furthermore, the system searches for related diseases using Forward Chaining. The result will be shown to the user by the system and user can print out it. Some of screenshot of the system during the testing are shown in Figure 6, Figure 7, Figure 8, and Figure 9 below: 


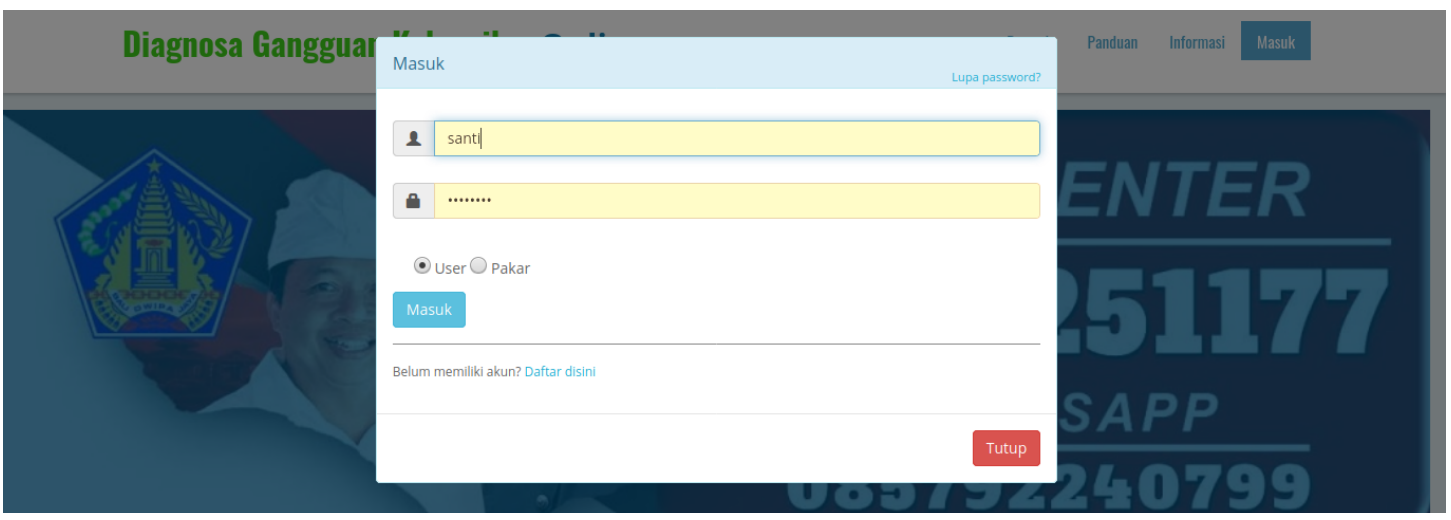

Figure 6. User Login to the System

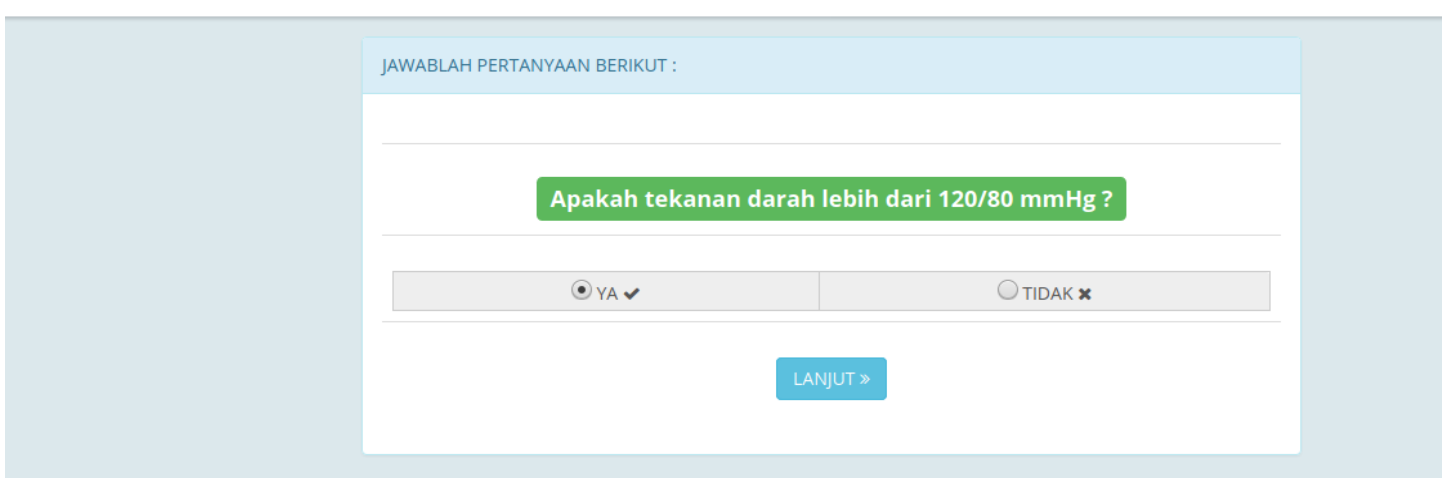

Figure 7. One of the Question from System to User During Diagnose

\section{Hasil Diagnosa}

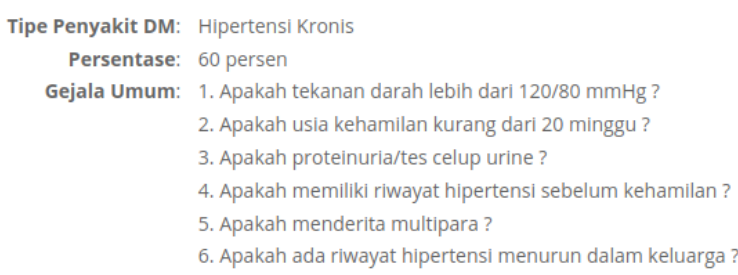

Definisi: Hipertensi kronis didefinisikan sebagai tekanan darah sistollk lebih atau sama dengan 140 mmhg dan atau tekanan darah diastolik lebih atau sama dengan $90 \mathrm{mmhg}$ yang telah ada sebelum kehamilan, yang bertahan sampal lebih dari 20 minggu pasca partus 1 atau setelah 12 minggu.

Pengobatan: Konsultasi ke dokter

Pencegahan: Selain minum obat sesuai yang diresepkan dan konsultasi dengan dokter secara teratur, Anda perlu merawat diri Anda sendiri untuk mengurangi risiko komplikasi jangka panjang hipertensi, seperti penyakit jantung atau ginjal dan stroke. Cobalah untuk mempertahankan gaya hidup sehat, memberikan perhatian khusus pada menu makan dan berat badan, hindari tembakau, dan membatasi alkohol yang Anda minum.

Waktu Diagnosa: 06 September 2020 23:23:43

Figure 8. Diagnose Result 


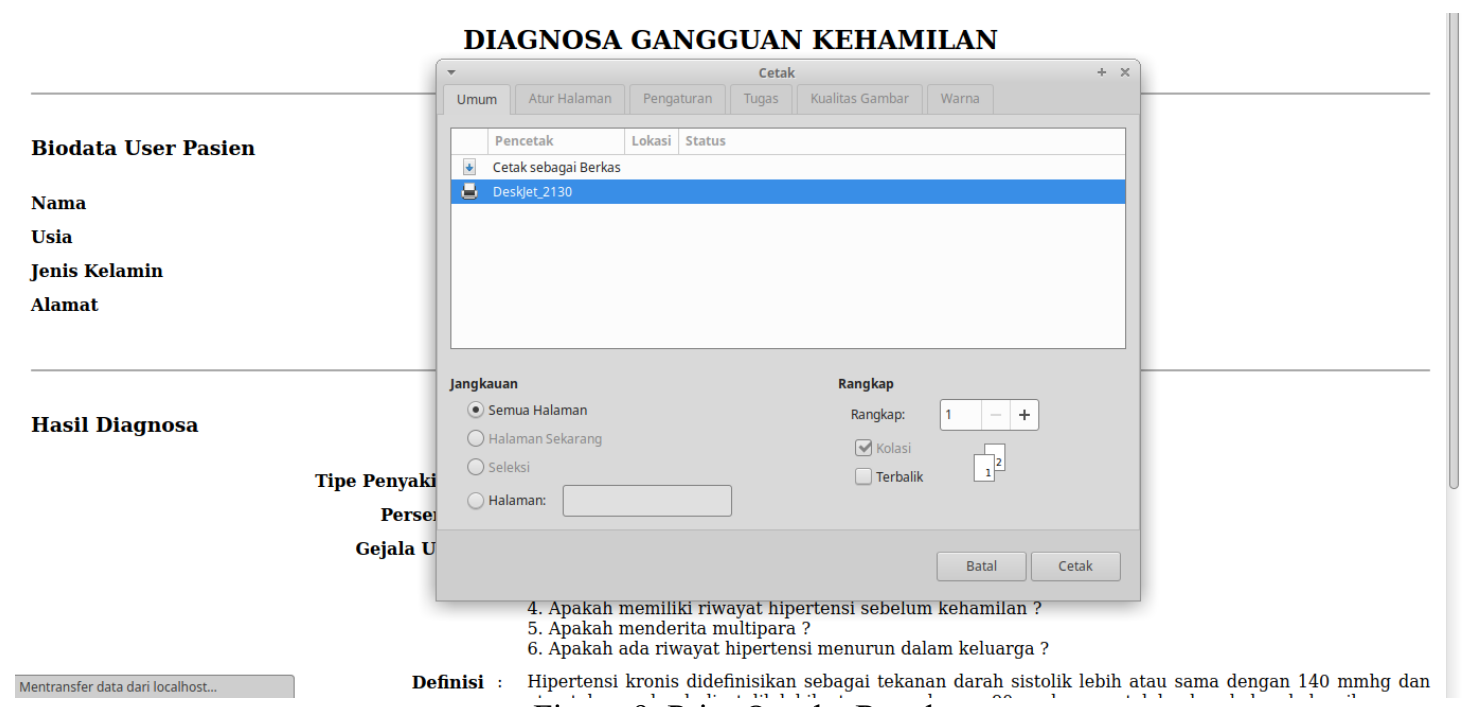

Figure 9. Print Out the Result

\subsection{The Experiment}

The testing of the experiment was executed by comparing the results of the expert system to the obtained information from the experts. The experts were some doctors from Obstetricians that having expertise in their field, with the result is some of pregnant women. The experimental scenario shows that the system was able to search for the specific diseases and disorders established.

\section{CONCLUSION}

From this research, the pregnant woman can do online self-diagnosis more easier and they also can print out the result. The system also more secure and reliable with Hybrid Cloud Computing technology. This expert system application can be well operated and is advised to be applied. This expert system can be analyzed and developed further. Dynamicization and interferences in the knowledge or diagnostic data such as data on symptoms, diseases, and other solutions can be developed further by the expert.

\section{ACKNOWLEDGEMENTS}

Gratitude to Dinas Kesehatan Provinsi Bali during this project, Universitas Udayana for the funding of this research, and Biznet-GEO for the support of NEO-CLI using the open-source Linux operating system.

\section{REFERENCES}

[1] Profil Kesehatan Provinsi Bali. Dinas Kesehatan Provinsi Bali. 2020. (online).

Retrieved: https://www.diskes.baliprov.go.id/profil-kesehatan-provinsi-bali

[2] N. Zahroh, Y. Findawati, "Sistem Pakar Diagnosa Penyakit Kista Ovarium Menggunakan Metode Certainty Factor Berbasis Web," Jurnal Sistem Informasi, Teknologi Informatika dan Komputer, Vol. 8, No. 2, pp. 76-80, 2016.

[3] Ajlan, "The Comparison Between Forward and Backward Chaining," International Journal of Machine Learning and Computing, Vol. 5, No. 2, pp. 106-113, 2015.

[4] K. Muludi, "Implementation of Forward Chaining and Certainty Factor Method on Android Based Expert System of Tomato Diseases Identification," International Journal of Advanced Computer Science and Applications (IJACSA), Vol. 9, No. 9, pp. 451-456, 2018.

[5] D.A. Prambudi, et al., "Expert System Application of Forward Chaining and Certainty Factors Method for The Decision of Contraception Tools," International Conference on Energy, Environment and Information System (ICENIS), pp. 1-6, 2017.

[6] Poningsih, et al., "Design of the Expert System to Analyze Disease in Plant Teak Using Forward Chaining," International Journal Of Artificial Intelegence Research, Vol. 1, No. 1, pp. 6-10, 2017.

[7] A.A. Pramesti, et al., "Expert System for Determination of Type Lenses Glasses using Forward Chaining Method," Scientific Journal of Informatics, Vol. 3, No. 2, pp. 177-188, 2016. 
[8] A. Rupnawar, et al., "Study on Forward Chaining and Reverse Chaining in Expert System," International Journal of Advanced Engineering Research and Science (IJAERS), Vol. 3, Issue. 12, pp. 1-3, 2016

[9] G.W. Sasmito, et al., "Application Expert System of Forward Chaining and The Rule Based Reasoning For Simulation Diagnose Pest and Disease Red Onion and Chili Plant," Proceedings of The 1st International Conference on Information Systems For Business Competitiveness (ICISBC), pp. 392-398, 2011.

[10] B.H. Hayadi, et al., "Expert System in the Application of Learning Models with Forward Chaining Method," International Journal of Engineering and Technology (IJET), Vol. 7, No. 2.29, pp. 845-848, 2018.

[11] Adriyendi, "Inference Menggunakan Forward Chaining Pada Food Affordability," Journal of Sainstek, Vol. 9, No. 2, pp.108-122, 2017.

[12] E.P. Gunawan, R. Wardoyo, "An Expert System Using Certainty Factor for Determining Insomnia Acupoint," Indonesian Journal of Computing and Cybernetics Systems (IJCCS), Vol.12, No.2, pp. 119 128, 2018.

[13] W.U. Setiabudi, et al., "Expert System Diagnosis Dental Disease Using Certainty Factor Method," Scientific Journal of Informatics, Vol. 4, No. 1, pp. 43-50, 2017.

[14] A.E. Saputri, et al., "Using Certainty Factor Method to Handle Uncertain Condition in Hepatitis Diagnosis," Journal of Computer, Mathematics and Engineering Applications (ComTech), Vol. 11, No. 1, pp. 1-10, 2020.

[15] K.E. Setyaputri, et al., "Comparative Analysis of Certainty Factor Method and Bayes Probability Method on ENT Disease Expert System," Scientific Journal of Informatics, Vol. 5, No.2, pp. 205-202, 2018.

[16] Y. Purnama, et al., "Expert System in Detecting Children's Intelligence using Certainty Factor," Journal of Critical Reviews, Vol 7, Issue. 1, pp. 52-55, 2020.

[17] L.A. Latumakulita, "Sistem Pakar Pendiagnosa Penyakit Anak Menggunakan Certainty Factor (CF)," Jurnal Ilmiah Sains, Vol. 12, No. 2, pp. 120-126, 2012.

[18] W.Y. Yulianti, et al., "Sistem Pakar Dengan Metode Certainty Factor Dalam Penentuan Gaya Belajar Anak Usia Remaja," Jurnal Teknologi Informasi Dan Komunikasi Digital Zone, Vol. 10, No. 2, pp. 120-130, 2019.

[19] S. Achmadi, et al., "Expert System Design to Diagnosa of Virus Infection Disease in Children with Certainty Factor Method," Journal of Science and Applied Engineering (JSAE), Vol. 1, No. 2, pp. 8895, 2018.

[20] Minarni, A. Fadhillah, "Expert System in Detecting Rice Plant Diseases Using Certainty Factor," International Journal of Dynamic Systems, Measurement and Control, Vol. 2, Issue. 1, pp.11-15, 2017.

[21] Q. Dan, J. Dudeck, "Certainty Factor Theory and its Implementation in a Medical Expert System Shell," Journal Medical Informatics, Vol. 17, Issue. 2, pp 1-10, 2018.

[22] G.P.A. Cruza, G.Beliakovb, "On the Interpretation of Certainty Factors in Expert Systems," Journal of Artificial Intelligence in Medicine, Vol. 8, Issue. 1, pp. 1-14, 2016.

[23] I. Sumatorno, et al., "Expert System of Catfish Disease Determinant Using Certainty Factor Method," International Journal of Recent Trends in Engineering and Research (IJRTER), Vol. 03, Issue. 08, pp. 202-209, 2017.

[24] Yuhandri, "Diagnosa Penyakit Osteoporosis Menggunakan Metode Certainty Factor," Jurnal Rekayasa Sistem dan Teknologi Informasi (RESTI), Vol. 2, No. 1, pp. 422-429, 2018.

[25] E. Panggabean, "Comparative Analysis Of Dempster Shafer Method With Certainty Factor Method For Diagnose Stroke Diseases," International Journal Of Artificial Intelegence Research, Vol. 2, No. 1, pp. 37-41, 2018.

[26] R. Annisa, "Sistem Pakar Metode Certainty Factor Untuk Mendiagnosa Tipe Skizofrenia," Indonesia Journal on Computer and Information technology (IJCIT), Vol. 3, No. 1, pp. 444-450, 2018.

[27] R. Siti, et al. "Sistem Pakar Menggunakan Metode Forward Chaining untuk Diagnosa Penyakit Tanaman Karet," Sultan Agung Fundamental Research Journal, Volume 1, No. 1, 2020.

[28] F. Yusra, "Sistem Pakar Menggunakan Forward Chaining dan Certainty Factor Untuk Diagnosa Kerusakan Smartphone", Jurnal Education and Development, vol. 8, no. 3, p. 337, 2020.

[29] R. Robby, et al. "Implementasi Metode Forward Chaining Untuk Diagnosa Penyakit Covid19 di RSUD Berkah Pandeglang Banten," Jurnal Teknologi Informasi (JTI), Vol.4, No.1, 2020.

[30] O. Pahlevi, and M.K. Atmojo, "The Utilization of Expert System The Utilization of Expert System for Diagnosing Diseases Cocoa Plants Based on Android Using the Forward Chaining Method," SinkrOn: Jurnal dan Penelitian Teknik Informatika, Vol. 4, No. 2, 2020. 
[31] R.E. Putri, et al., "Penerapan Metode Forward Chaining Pada Sistem Pakar Untuk Mengetahui Kepribadian Seseorang," INTECOMS: Journal of Information Technology and Computer Science, Vol.3, No.1, pp.60-66, 2020.

[32] I. Syahputri, et al., "Sistem Pakar dengan Proses Forward Chaining pada Kulit Wajah Berminyak," Journal of Information Sistem Research (JOSH), Vol.2, No. 1, pp. 26-34, 2020.

[33] A. Abdillah, et al., "Perancangan Sistem Pakar Diagnosa Penyakit Kehamilan Berbasis Web," Jurnal TECHNO Nusa Mandiri, Vol. 15, No. 2, pp. 1-6, 2018.

[34] A. Aji, et al., "Sistem Pakar Diagnosa Penyakit Ibu Hamil Menggunakan Metode Certainty Factor (CF)," Jurnal Pengembangan Teknologi Informasi dan Ilmu Komputer, vol. 2, no. 5, pp. 2127-2134, 2017.

[35] R. Maryani, D. Haryanto, "Sistem Pakar Diagnosa Penyakit Pada Ibu Hamil Dengan Metode Forward Chaining," Jurnal Manajemen dan Teknik Informatika (JUMANTAKA), Vol. 1. No. 1, pp.151-160, 2017.

[36] A. Hasbiyanor, Bahar, "Sistem Pakar Diagnosa Keluhan Selama Masa Kehamilan Menggunakan Metode Certainty Factor Berbasis Web," Jurnal Ilmiah Teknik Informatika dan Sistem Informasi (Jutisi) Vol. 6, No. 1, pp. 1311-1448, 2017.

[37] F.N. Afiana, et al., "Perancangan Metode Forward Chaining Untuk Mendeteksi Dini Gangguan Masa Kehamilan," Conference on Information Technology, Information System and Electrical Engineering (CITISEE), pp. 78-82, 2017.

[38] W.F. Mustafa, Kusrini, "Sistem Pakar Diagnosa Penyakit Pada Ibu Hamil Menggunakan Teorema Bayes Di Apotek Rumah Sederhana Jayapura," Information System Journal (INFOS), Vol. 1 No. 3, pp. 33-39, 2020.

[39] J. Minardi, Suyatno, "Sistem Pakar Untuk Diagnosa Penyakit Kehamilan Menggunakan Metode Dempster-Shafer dan Decision Tree," Jurnal Teknik Mesin, Elektro dan Ilmu Komputer Seri Teknologi (SIMETRIS), Vol. 7, No. 1, pp. 83-98, 2016.

[40] R. Fauzan, A.V. Prananda, "Expert System for Diagnosing Palm Tree Diseases and Pests using Forward Chaining and Certainty Factor," Jurnal Kinetik, Vol. 3, No. 1, Pp. 27-34, 2018. 